\title{
PENGOLAHAN LIMBAH BIJI SALAK KELOMPOK USAHA MANDIRI DI DESA AEK NABARA KECAMATAN ANGKOLA BARAT
}

\author{
Qorry Hilmiyah Harahap $^{1 *}$, Mukhlis ${ }^{2}$, Amir Mahmud Harahap ${ }^{3}$ \\ ${ }^{\text {I}}$ Fakultas Pertanian, Universitas Muhammadiyah Tapanuli Selatan, Padang Sidimpuan \\ *Penulis Korespondensi: qorryalqis79@gmail.com
}

\begin{abstract}
Abstrak
Padang sidimpuan terkenal dengan kota salak, akan tetapi pada masa-masa tertentu harga salak menjadi sangat murah. Mengatasi hal tersebut muncul ketika kehidupan petani salak yang semakin sulit dalam menghadapi musim panen raya tiba sementara harga salak anjlok dan salak yang kulitnya terkelupas sehingga kondisi salak bagus terbuang percuma (istilah petani setempat salak "pamilian") dari kondisi inilah muncul ide pembuatan makan dan minuman dari olahan buah salak. Selama ini, Kelompok Usaha Mandiri di Desa Aek Nabara ingin mengembangkan usaha kopi biji salak namun terkendala dalam proses produksi, pengemasan kopi biji salak, pemasaran serta laporan pembukuan kelompok usaha. Kegiatan ini bertujuan untuk membantu Kelompok Usaha Mandiri dalam proses produksi kopi biji salak, pengemasan produk, pemasaran serta laporan pembukuan sehingga dapat meningkatkan pendapatan Kelompok Usaha Mandiri. Kegiatan pengabdian kepada masyarakat dilaksanakan dengan metode pelatihan dan praktek penggunaan alat penggiling biji salak, praktek pengemasan produk, pelatihan pemasaran dan praktek pembuatan laporan keuangan. Hasil yang dicapai dari kegiatan pengabdian kepada masyarakat ini adalah Kelompok Usaha Mandiri mampu memproduksi kopi biji salah, pengemasan produk, pemasaran kopi biji salak dan laporan pembukuan Kelompok Usaha Mandiri.
\end{abstract}

Kata kunci : Kopi Biji Salak, Alat Penggiling Biji Salak, Kelompok Usaha Mandiri, Desa Aek Nabara, Padangsidimpuan

\begin{abstract}
Padang sidimpuan famous for the city of barking, but at certain times the price of barking becomes very cheap. Overcome this occurs when the life of salak farmers who increasingly difficult in the face of harvest season arrive while the price of salak plummeted and barked peeled skin so that good salak conditions wasted (the term local farmer salak "pamilian") from this condition came the idea of making food and drink of processed fruit bark. During this time, the Independent Business Group in Aek Nabara Village wants to develop the business of salak seed coffee but is constrained in the production process, packing of salak seed coffee, marketing and bookkeeping report of business group. This activity aims to assist the Independent Business Group in the production process of salak seed coffee, product packaging, marketing and bookkeeping report so as to increase the income of Independent Business Group. Community service activities are carried out with the method of training and the practice of using the seed grinder tool, the practice of product packaging, marketing training and financial reporting practice. The results achieved from this community service activity are Independent Business Group able to produce wrong coffee beans, product packaging, marketing of salak seed coffee and report bookkeeping of Independent Business Group.
\end{abstract}

Keywords: Salak Seed Coffee, Salak Seed Mill, Independent Business Group, Aek Nabara Village, Padangsidimpuan

\section{PENDAHULUAN}

Terbentuknya kelompok usaha mandiri dikarenakan sekelompok masyarakat khususnya ibu-ibu rumah tangga dan petani salak terpacu untuk melakukan usaha dengan harapan dapat mengatasi masalah keuangan keluarga yang mereka hadapi. Mahalnya biaya pendidikan, kesehatan dan kebutuhan pokok membuat mitra harus bekerja keras untuk dapat tetap eksis dalam menghadapi kondisi ekonomi yang serba tidak menentu. Mahalnya harga bahan bakar minyak (BBM) menambah persoalan tersendiri bagi mitra dimana mahalnya harga BBM telah memacu kenaikan hargaharga bahan pokok lainnya. Untuk mengatasi hal tersebut muncul ketika kehidupan petani salak yang semakin sulit ketika musim panen raya tiba sementara harga salak anjlok dan salak yang kulitnya terkelupas sementara kondisi salak bagus terbuang 
percuma (istilah petani setempat salak "pamilian") dari kondisi inilah muncul ide pembuatan makan dan minuman dari olahan buah salak, selain membantu petani, produk olahan ini menambah usia jual dari buah salak, yang dulunya hanya bisa dijual 3- 7 hari kini produk olahan bisa tahan hingga tahunan.

Setelah beberapa waktu berjalan usaha yang mitra lakukan ternyata membuahkan hasil, ini dibuktikan dengan meningkatnya pendapatan mitra yang secara langsung sangat membantu ekonomi keluarga dan mitra sedikit lega karena untuk biaya pendidikan anak usaha yang mitra lakukan dapat diandalkan. Namun demikian, terkadang usaha yang mitra lakukan mengalami pasang surut.

Anggota kelompok usaha mandiri sampai sekarang ini sudah mencapai kurang lebih 13 orang dan diharapkan akan terus bertambah seiring berjalannya waktu. Oleh karena itu, tak mengherankan bila kelompok usaha mandiri ini menjadi salah satu wadah bagi masyarakat di Desa Aek Nabara Kecamatan Angkola Barat yang ingin melakukan aktifitas usaha dalam membantu memenuhi ekonomi keluarganya.

Kelompok Usaha Mandiri yang jumlah anggotanya sebanyak 13 orang menjalankan aktifitas usaha yaitu memproduksi kripik salak, manisan salak, dodol salak, agar-agar salak, serta memproduksi juga minuman segar yang biasanya mereka jual untuk keperluan pesta atau resepsi juga para wisatawan yang berkunjung ke kota salak. Kelompok Usaha Mandiri yang memproduksi makanan jajanan khas kota salak dan juga memproduksi jus salak yang diketuai oleh Ibu Sry lestari dan Ibu Saleha batubara. Mitra tersebut ingin mengembangkan usahanya, namun karena keterbatasan pengetahuan dalam pengelolaan dan manajemen usaha, kegiatan ini belum terlaksana dengan baik dan kelompok usaha mandiri belum pernah mendapat pengarahan ataupun pengetahuan tentang pengelolaan dan manajemen usaha dari pihak pemerintah dan pihak manapun. Kelompok usaha Mandiri belum pernah mengajukan permohonan kredit ke lembaga perbankan manapun dalam rangka ingin mengembangkan usaha, hal ini dikarenakan keterbatasan wawasan, pengetahuan dan pengalaman yang mitra miliki sehingga mereka kesulitan untuk mengembangkan usahanya dalam melakukan inovasi produk dengan memanfaatkan sumber daya atau limbah salak yang tidak dimanfaatkan. Perguruan Tinggi yang merupakan sentral ilmu pegetahuan, yang menjalankan perannya sebagai pelayan mahasiswa dan masyarakat, berkeinginan membantu mitra untuk mengembangkan kelompok usaha mandiri menjadi lebih baik dari sebelumnya.

Berdasarkan kondisi mitra, kelompok usaha mandiri ini ingin mengembangkan usahanya dengan mengoptimalkan pengetahuan dalam mengelola dan manajemen usaha sehingga mudah bagi mitra untuk mengambangkan usaha yang dilakukannya.

\section{METODE PELAKSANAAN}

Berdasarkan permasalahan yang telah dikemukakan, maka dalam kegiatan IbM ini metode pelaksanaan yang digunakan, yaitu:

1. Memberikan pendidikan dan pelatihan manajemen usaha

2. Pendidikan dan pelatihan praktek produksi

3. Pendidikan dan pelatihan desain kemasan

4. Pelatihan penyusunan laporan keuangan usaha kecil

\section{HASIL DAN PEMBAHASAN}

Kegiatan program IbM Pengelolaan Limbah Salak Kelompok Usaha Mandiri di Desa Aek Nabara Kecamatan Angkola Barat dilaksanakan berdasarkan atas perencanaan yang telah dibuat. Sampai saat ini kegiatan yang sudah dilakukan atau hasil yang sudah dicapai adalah sebagai berikut:

1. Pendidikan dan Pelatihan Manajemen Usaha.

Kegiatan ini dilaksanakan dikediaman Ibu Sry Lestari yang bertempat di Jalan Sibolga Km 11 Desa Aek Nabara Kecamatan Angkola Barat Kabupaten Tapanuli Selatan. Kegiatan ini dihadiri oleh 20 orang peserta dari kelompok usaha mandiri dengan narasumber dari tim pelaksana IbM dengan menggunakan metode ceramah dan diskusi. Dalam kegiatan ini, mitra diajarkan bagaimana mengelola sebuah usaha dengan menggunakan standar operasional prsedur mulai dari sistem manajemen usaha, manajemen produksi, manajemen pemasaran dan manajemen keuangan dan yang paling penting adalah bagaimana para pelaku kelompok usaha mandiri mampu mengelola usahanya secara profesional. Pada pertemuan ini juga mendiskusikan tentang perihal kegiatan yang akan dilakukan pada pertemuan selanjutnya, sehingga para kelompok usaha mandiri mampu mempersiapkan diri dan keperluan lainnya untuk kegiatan pendidikan dan pelatihan produksi.

2. Pendidikan dan Pelatihan Praktek Produksi

Kegiatan ini dilaksanakan dikediaman Ibu Sry Lestari yang bertempat di Jalan Sibolga Km 11 Desa Aek Nabara Kecamatan Angkola Barat Kabupaten Tapanuli Selatan. Pada pelatihan dan praktek produksi, tim pelaksana IbM mengundang instruktur dari Sidikalang Kabupaten Dairi, Sumatera Utara yaitu Ibu Andri dan Ibu Yunita yang merupakan pengusaha kopi sidikalang dan telah berpengalaman dalam memproduksi kopi baik itu dari biji kopi asli maupun inovasi kopi dari biji salak. Dalam kegiatan ini, terdapat total 20 (dua puluh) peserta yang turut ambil bagian dalam melakukan proses produksi biji salak untuk dijadikan kopi. Pola pendidikan dan pelatihan serta praktek produksi ini menggunakan pendekatan bimbingan teknis dimana 20 peserta tersebut dibimbing secara insentif dalam pembuatan kopi berbahan biji salak tersebut, yang bahannya sangat banyak ditemukan dari limbah pengolahan buah salak usaha Ibu Sry Lestari dan Ibu Soleha Batubara. 
3. Pendidikan dan Pelatihan Desain Kemasan

Pada proses pelaksanaan pendidikan dan pelatihan desain kemasan, tim pelaksana IbM mengundang instruktur yang sama pada saat pelaksanaan pendidikan dan pelatihan produksi biji salak menjadi kopi yaitu Bapak Andri dan Ibu Yunita. Metode yang digunakan dalam pendidikan dan pelatihan ini menggunakan pendekatan bimbingan teknis secara insentif. Proses pengemasan merupakan tahap yang dilakukan setelah proses filterisasi atau penghalusan tahap akhir. Kemasan yang digunakan adalah plastik dan alluminium foil yang memiliki tingkat ketebalan 90 micron. Berat masing-masing kemasan ada yang 250 gr dan 500gr dan diberi label pada setiap produk yang dikemas.

4. Pelatihan Penyusunan Laporan Keuangan Usaha

Kecil

Untuk mempersiapkan peserta menjadi wirausaha yang profesional, tim IbM membekali peserta dengan pendidikan dan pelatihan pengelolaan manajemen keuangan dan penyusunan laporan keuangan sederhana UMKM dengan metode ceramah dan praktek. Selain itu, dalam tahap ini juga disertakan pemaparan dan diskusi mengenai pemanfaatan teknologi seperti komputer atau laptop dan sejenisnya untuk membuat laporan keuangan baik itu menggunakan software Microsoft Office Excel maupun Microsoft Office Word. Sehingga nantinya mitra mampu mengelola keuangan usaha yang dilakukan dengan mandiri.

\section{KESIMPULAN DAN SARAN}

Berdasarkan kepada tingginya antusiasme mitra yang terlibat dalam kegiatan ini, dapat kami simpulkan bahwa kegiatan IbM Pengelolaan Limbah Salak Kelompok Usaha Mandiri di Desa Aek Nabara Kecamatan Angkola Barat dalam pembuatan kopi berbahan limbah salah yaitu biji salak memberikan dampak yang nyata dan tepat guna kepada seluruh peserta. Melalui pendekatan proses produksi kopi yang sederhana dan aplikatif serta penggunaan bahan baku yang mudah didapat, peserta mampu menerapkan pengetahuan dan teknik yang diperoleh selama mengikuti pelatihan untuk memenuhi kebutuhan sehari-hari. Lebih luas lagi, dengan produksi kopi berbahan dasar biji salak tersebut secara berkesinambungan, masyarakat khususnya mitra akan memiliki alternatif penghasilan tambahan guna meningkatkan kesejahteraan ekonomi kelompok usaha tersebut.

Program serupa diharapkan dapat dilaksanakan ke dalam kelompok usaha mandiri di lokasi yang berbeda, khususnya di Kabupaten Tapanuli Selatan. Sehingga, akan dapat memberikan manfaat yang lebih luas serta mendukung program nasional pemberdayaan masyarakat madani. Selain itu, dengan pemberdayaan kreativitas masyarakat melalui program seperti ini secara luas diharapkan dapat meningkatkan kesejahteraan masyarakat. 